\title{
Establishing Irrigation Levels Targeting Higher Content of Lycopene and Water Use Efficiency in Tomato
}

\author{
Fábio T. Delazari ${ }^{1}$, Ronaldo S. Gomes ${ }^{1}$, Bruno S. Laurindo ${ }^{1}$, Renata D. F. Laurindo ${ }^{1}$, Luan B. Giovanelli ${ }^{2}$, \\ Davi S. de Freitas ${ }^{1}$, Everardo C. Mantovani ${ }^{2} \&$ Derly J. H. da Silva ${ }^{1}$ \\ ${ }^{1}$ Plant Science Department, Federal University of Viçosa, University Campus, Viçosa, MG, Brazil \\ ${ }^{2}$ Agricultural Engineering Departament, Federal University of Viçosa, University Campus, Viçosa, MG, Brazil \\ Correspondence: Ronaldo S. Gomes, Plant Science Department, Federal University of Viçosa, University \\ Campus, Viçosa, MG, Brazil. Tel: 55-319-9751-6432. E-mail: irm.7rg@hotmail.com
}

Received: August 22, 2018

Accepted: October 15, 2018

Online Published: December 15, 2018

doi:10.5539/jas.v11n1p209

URL: https://doi.org/10.5539/jas.v11n1p209

\begin{abstract}
The demand for healthier foods has been increasing worldwide. Associated with this trend, it is crucial to optimize the use of inputs for ensuring the sustainability of production. The fruits of tomato are important sources of minerals, vitamins, and especially of carotenoids such as the lycopene. This carotenoid plays biological activities that are crucial such as the antioxidant function, besides its proven action in the prevention of cancers and degenerative diseases. The irrigation seems to play a fundamental role in the biosynthesis of lycopene. Thus, it is fundamental to establish levels of irrigation that might provide higher content of lycopene, productivity, and efficiency in the use of water in the production of tomato. The objective of this study was to establish adequate levels of irrigation for the obtainment of higher content of lycopene, productivity of fruits, and higher efficiency in the use of water in the production of salad tomato. For this, two experiments were carried in different cropping seasons. The treatments consisted of the application of four irrigation depths, corresponding to $50,100,150$ and $200 \%$ of the tomato evapotranspiration. The estimates of maximum productivity corresponded to the application of the irrigation depth of $112 \% \mathrm{ETc}$, while the maximum content of lycopene and the higher efficiency in the use of water corresponded to $50 \%$ ETc. The irrigation depth of $100 \%$ ETc is recommended as the best irrigation depth to obtain higher content of lycopene, productivity, and efficiency in the use of water jointly.
\end{abstract}

Keywords: carotenoids, fruit quality, Solanum lycopersicum

\section{Introduction}

The tomato (Solanum lycopersicum L.), is worldwide one of the most important vegetables in terms of fresh consumption and in industrialized forms. The tomato plays an important nutritional role as a source of nutrients such as vitamin C and precursors of vitamin such as the vitamin A (Leiva-Brondo et al., 2012). A remarkable nutritional aspect in this crop is the high number of nutritional components on its fruits, important to human health, especially those with antioxidant activity (Ilahy et al., 2011). The antioxidant activity related to the consumption of tomato stems from the presence of components on its fruits such as Vitamin $\mathrm{C}$, carotenoids as $\beta$-carotene and lycopene, besides phytonutrients such as flavonoids (Pernice et al., 2010; Perveen et al., 2015).

The lycopene is responsible for the reddish coloration of mature fruits of tomato and represents most of the carotenogenic content on its fruits. Although this carotenoid has not provitamin A activity, it has a pronounced antioxidant capacity that protects the cell layer against free radicals (Aidoud, Ammouche, Garrido, \& Rodriguez, 2014). Several studies have been conducted in order to investigate the antioxidant capacity resulting from the consumption of tomato, and they have associated the consumption of lycopene to the prevention of degenerative diseases, certain cancers and cardiovascular diseases (Caliman et al., 2010; Kong et al., 2010; Perveen et al., 2015).

The content of lycopene on fruits of tomato is related to innumerous factors such as the cultivated variety, cropping region, maturation stage, besides agronomic practices as irrigation and fertilizing (Ilahy et al., 2011). Among these factors, the irrigation seems to have a pronounced effect in the biosynthesis of lycopene (Navarro, 
Botía, \& Pérez-Pérez, 2015; Navarro, Pérez-Pérez, Romero, \& Botía, 2010; Pék et al., 2014). Associated to this, the tomato is known for the high requirements of water during its cultivation (Patanè, Tringali, \& Sortino, 2011).

In general, the studies investigating the effect of irrigation in the content of lycopene in tomato show that the reduction of irrigation and the imposition of water stress in this crop has resulted in an increase in the content of carotenoid in fruits (Pék et al., 2014). On the other hand, some studies showed that water deficit decreased the content of lycopene in fruits of some varieties of tomato (Liu et al., 2011). The disagreement between these results stems from the edaphoclimatic differences between the regions of study and probably, from the different methods of irrigation adopted, as well as from the contrast in the responsive capacity of the studied genotypes to the different hydric conditions. This points out to the need to study the establishment of the ideal management of irrigation in each region of cultivation.

Already consolidated in the cultivation of salad tomato, the drip irrigation system became crucial in this crop for resulting in a lower incidence of aerial diseases. Other attractive aspect in the use of drip irrigation is the greater uniformity in the application of water that it provides (Ozbahce \& Tari, 2010). Corroborating this, The reduced availability of water and the global concern with this resource (Li, Shi, Šmůnek, Gong, \& Peng, 2015; López-Mata, Tarjuelo, de Juan, Ballesteros, \& Domínguez, 2010), corroborates the importance of studies targeting strategies that might result in greater efficiency in the use water in agriculture (Navarro et al., 2015). In this context, the water use efficiency index (WUE), represents a valuable tool for guiding the planning of irrigation and the decision making, targeting a more efficient use of water in agricultural production (Karatas, Akkuzu, Unal, Asik, \& Avci, 2009). Thus, the objective of this study was to evaluate the productivity of tomato, the content of lycopene in fruits, and the WUE in this crop at different levels of irrigation.

\section{Materials and Methods}

\subsection{Seasons and Experimental Conditions of the Experiments}

Two field experiments were carried in two different seasons in order to test the response of the treatments in contrasting and representative seasons of cultivation. The first experiment was conducted from June to November 2013 (Winter/Spring), and the second, from January to May 2014 (Summer/Autumn), both in the Department of Plant Science, in the Federal University of Viçosa, in Viçosa, Minas Gerais, Brazil. The experiments were located at $20^{\circ} 45^{\prime} \mathrm{S}$ latitude and e $42^{\circ} 52^{\prime} \mathrm{W}$ longitude.

The analysis of soil texture was carried out before setting the experiments. The soil in the first experiment was classified as clay soil in the layer $(0-40 \mathrm{~cm})$, and as frank-clay-sandy $(0-20 \mathrm{~cm})$. In the second experiment, the soil was classified as clay-sandy $(20-40 \mathrm{~cm})$. This classification was based on the classification of Lemos and Santos (1996), and the informations are shown in (Table 1).

Table 1. Physical properties of the soil in the experimental areas in the two cropping seasons Winter/Spring and Summer/Autumn. Viçosa, Minas Gerais state, Brazil. 2013/2014

\begin{tabular}{|c|c|c|c|c|}
\hline \multirow{2}{*}{$\begin{array}{l}\text { Experiment } \\
\text { Depth }(\mathrm{cm})\end{array}$} & \multicolumn{2}{|c|}{ Winter/Spring } & \multicolumn{2}{|c|}{ Summer/Autumn } \\
\hline & $0-20$ & $20-40$ & $0-20$ & $20-40$ \\
\hline$\theta_{\mathrm{FC}}\left(\mathrm{m}^{3} \mathrm{~m}^{-3}\right)^{1}$ & 0.49 & 0.53 & 0.44 & 0.44 \\
\hline$\theta_{\mathrm{WP}}\left(\mathrm{m}^{3} \mathrm{~m}^{-3}\right)^{2}$ & 0.34 & 0.39 & 0.26 & 0.27 \\
\hline Clay $\left(\mathrm{kg} \mathrm{kg}^{-1}\right)^{3}$ & 0.41 & 0.42 & 0.32 & 0.37 \\
\hline Silt $\left(\mathrm{kg} \mathrm{kg}^{-1}\right)^{3}$ & 0.20 & 0.19 & 0.05 & 0.12 \\
\hline Sand $\left(\mathrm{kg} \mathrm{kg}^{-1}\right)^{3}$ & 0.39 & 0.39 & 0.63 & 0.51 \\
\hline
\end{tabular}

Note. ${ }^{1}$ Field capacity $\left(\theta_{\mathrm{FC}}\right)$, wilting point ${ }^{2}\left(\theta_{\mathrm{WP}}\right)$, and ${ }^{3}$ textural classification according to the Brazilian Society of Soil Science.

\subsection{Genotype Information, Prepare of Seedlings and Cultivation Management}

We evaluated the commercial hybrid Carina TY, which is commercialized by the Sakata Seed-Brazil. This hybrid is a salad tomato with undetermined growth, widely cultivated in Brazil, with a high productive potential and a high quality of fruits.

The seedlings were produced in polystyrene trays with 128 cells using the commercial substrate Golden Mix (Amafibra), made of coconut fiber. The seedlings were transplanted when they had 3 to 4 fully expanded leaves. The arrangement of plants resulted in a density of 2.5 plants $\mathrm{m}^{-2}$, and a population of 25.000 plants ha $^{-1}$. The 
agricultural management was performed on a weekly basis, and pests and diseases were controlled whenever necessary according to the recommendations of (Valenciano \& Toril, 2015).

The acidity of the soil was corrected before the experiments were set and the fertilizing was performed according to the recommendation of fertilizing used in the state of Minas Gerais, Brazil, known as the Quinta Aproximação (Ribeiro et al., 1999). The soil $\mathrm{pH}$ was adjusted applying $410 \mathrm{~kg} \mathrm{ha}^{-1}$ of dolomitic limestone, RPTN $=85 \%$, in the first experiment, and $395 \mathrm{~kg} \mathrm{ha}^{-1}$ in the second. The limestone was applied at $20 \mathrm{~cm}$, one week before the transplanting, in both experiments.

The initial fertilizing was not performed in the experiments and the application of fertilizing was divided into 18 sessions in both experiments. The doses of nutrients was the same among the treatments and the fertilizing was gradually applied in the irrigation pipe with a venturi injector, from the first week of transplanting. The fertilizers used in both experiments were mono-ammonium phosphate (MAP), calcium nitrate $\left(\mathrm{Ca}_{3}(\mathrm{NO})_{2}\right)$, potassium chloride $(\mathrm{KCl})$, and magnesium sulfate $\left(\mathrm{MgSO}_{4}\right)$ (Table 2).

Table 2. Recommendation of fertilizing used in the state of Minas Gerais, Brazil, adapted from the Quinta Aproximação, Ribeiro et al. (1999)

\begin{tabular}{|c|c|c|c|}
\hline \multicolumn{4}{|l|}{ Planting Fertilizing } \\
\hline \multirow{2}{*}{ Availability of $\mathrm{P}$ and $\mathrm{K}$} & \multicolumn{3}{|c|}{ Doses } \\
\hline & $\mathrm{N}$ & $\mathrm{P}_{2} \mathrm{O}_{5}$ & $\mathrm{~K}_{2} \mathrm{O}$ \\
\hline & $----\cdot$ & ------ & \\
\hline Low & 0 & 900 & 80 \\
\hline Medium & 0 & 800 & 60 \\
\hline Good & 0 & 600 & 40 \\
\hline Excellent & 0 & 400 & 0 \\
\hline \multicolumn{4}{|l|}{ Post Planting Fertilizing } \\
\hline \multirow{2}{*}{ Period of application } & \multicolumn{3}{|c|}{ Doses } \\
\hline & $\mathrm{N}$ & $\mathrm{P}_{2} \mathrm{O}_{5}$ & $\mathrm{~K}_{2} \mathrm{O}$ \\
\hline $1^{\text {st }}$ to $4^{\text {th }}$ Week & 30 & 80 & 40 \\
\hline $5^{\text {th }}$ to $8^{\text {th }}$ Week & 60 & 48 & 70 \\
\hline $9^{\text {th }}$ to $14^{\text {th }}$ Week & 90 & 36 & 130 \\
\hline After the $15^{\text {th }}$ Week & 120 & 0 & 180 \\
\hline
\end{tabular}

\subsection{Irrigation Management}

A drip tape with a flow rate of 1.39 and $1.10 \mathrm{Lh}^{-1}$ and a Christiansen uniformity coefficient (CUC) of 96.1 and $97.8 \%$ was used in the Winter/Spring and Summer/Autumn experiments, respectively. The drip tape worked at a pressure of $9.0 \mathrm{mca}$ in both experiments. The flow rate in each experiment was determined based on the sampling of 16 random points in the experimental area. For this, we measured the flow rate from 4 drip tapes, collecting from 4 points in each drip tape. The CUC was calculated according to the equation below:

$$
\mathrm{CUC}=\left[1-\frac{\sum_{\mathrm{i}=1}^{\mathrm{n}}\left|\mathrm{q}_{1}-\overline{\mathrm{q}}\right|}{\mathrm{n} \times \overline{\mathrm{q}}}\right] \times 100
$$

The irrigation was carried out based on a two-to-three day frequency, and the water demand was calculated by estimating the evapotranspiration (ETc) for the crop of tomato. The water demand of the crop was determined by adjusting the coefficients to the evapotranspiration reference $\left(\mathrm{ET}_{0}\right)$. The net irrigation depth was calculated by the water balance, considering the water intake for irrigation and precipitation as well its output by evapotranspiration.

The crop evapotranspiration was estimated based on the Equations 1 and 2:

$$
\begin{gathered}
\mathrm{ETc}=\mathrm{ET}_{0} \times \mathrm{K}_{\mathrm{c}} \\
\mathrm{K}_{\mathrm{c}}=\left(\mathrm{K}_{\mathrm{cb}} \times \mathrm{K}_{\mathrm{s}}\right)+\mathrm{K}_{\mathrm{e}}
\end{gathered}
$$

Where, ETc $=$ crop evapotranspiration $\left(\mathrm{mm} \mathrm{d}^{-1}\right), \mathrm{ET}_{0}=$ reference evapotranspiration $\left(\mathrm{mm} \mathrm{d}^{-1}\right), \mathrm{K}_{\mathrm{c}}=$ crop coefficient, $\mathrm{K}_{\mathrm{cb}}=$ crop basal coefficient, $\mathrm{K}_{\mathrm{e}}=$ soil evaporation coefficient, and $\mathrm{K}_{\mathrm{s}}=$ stress coefficient (Allen et al., 1998). 
The cycle of the crop was divided into phenological stages, and a different value of Kcb was assumed for each one. This was necessary because the values of Kcb in tomato change according to the stages of development of this crop and according to the edaphoclimatic conditions (Allen \& Pereira, 2009). Thus, the ETc was determined based on the initial, intermediate, and final values of the $\mathrm{K}_{\mathrm{cb}}$, which corresponded to $0.15,1.15$, and 0.70 , respectively (Allen et al., 1998).

The first phenological stage initiated soon after the transplanting of seedlings and lasted until the crop covered $10 \%$ of the area. This stage comprised a period of nine days in the Winter/Spring experiment and nineteen days in Summer/Autumn experiments. The second stage lasted 31 days in the first experiment, and 15 days in the second, and it was completed when the crop covered about $75 \%$ of the area. The third stage began with the harvesting of fruits, when the crop had covered about $75 \%$ of the area, and lasted 45 days in the first experiment, and 30 days in the second. The last stage lasted until the end of harvesting and corresponded to a period of 57 days in the first experiment, and 62 days in the second.

The application of the irrigation treatments initiated 19 days after transplanting (DAT), when the plants had 119 Degree Days (DD), and continued during the phases of development, production and harvest. The values of DD used as a reference to these three phases corresponded to 306, 661 and 1246.

The irrigation frequency and the total volume of water for each treatment (irrigation + precipitation) are described in the Table 3.

Table 3. Rain and irrigation applied during the conduction of the experiments in the two cropping seasons: Winter/Spring and Summer/Autumn

\begin{tabular}{|c|c|c|c|c|}
\hline Experiment & Irrigation $(\% \mathrm{ETc})$ & Rain (mm) & Irrigation $(\mathrm{mm})$ & Rain and Irrigation $(\mathrm{mm})$ \\
\hline \multirow[t]{4}{*}{ Winter/Spring } & 50 & 257 & $123(44)^{\mathrm{a}}$ & 380 \\
\hline & 100 & 257 & $236(44)$ & 493 \\
\hline & 150 & 257 & $348(44)$ & 605 \\
\hline & 200 & 257 & $461(44)$ & 718 \\
\hline \multirow[t]{4}{*}{ Summer/Autumn } & 50 & 317 & $91(21)$ & 408 \\
\hline & 100 & 317 & $171(21)$ & 488 \\
\hline & 150 & 317 & $235(21)$ & 552 \\
\hline & 200 & 317 & $306(21)$ & 623 \\
\hline
\end{tabular}

Note. ${ }^{\text {a }}$ The values in parentheses are the number of irrigation events.

\subsection{Experimental Design}

The treatments were evaluated in rows $14 \mathrm{~m}$ long. The experimental plot consisted of rows $3 \mathrm{~m}$ long, with 15 plants distributed in a $0.2 \times 2.0 \mathrm{~m}$ spacing. During the evaluations, only the four central plants were considered as the useful area.

The experiment was conducted in a randomized block design, with three replications. The treatments consisted of irrigation depths corresponding to 50,100, 150 and $200 \%$ of the crop ETc.

\subsection{Experimental Analyses}

The fruits were collected and classified into three commercial classes (large: those with diameter greater than 60 $\mathrm{mm}$, medium: diameter between 50 and $60 \mathrm{~mm}$, and small: diameter between 40 to $50 \mathrm{~mm}$ ). Samples were collected from five fruits randomly chosen from each treatment. Outer parts of these fruits were taken by transversal cuts and were processed together on a blander in order to obtain representative samples. The samples were kept under refrigeration, at $-80{ }^{\circ} \mathrm{C}$, for two days before the analysis.

The content of lycopene of each treatment was estimated by spectrophotometric analysis of tree samples, after thawing them. Samples with $15 \mathrm{~mL}$ acetone were macerated in a mortar and filtered through a Buchner funnel with vacuum. This operation was repeated four times until the residue became colorless, and then $25 \mathrm{~mL}$ of petroleum was added to the separatory funnel. Carotenoids were transferred to a separatory funnel, discarding the lower phase. The samples were washed four to five times to completely remove the acetone. The petroleum ether solution of the pigment was transferred to a volumetric flask. The volume of this flask was brought to 25 $\mathrm{mL}$ with petroleum ether. The absorbance spectrophotometer (BEL PHOTONICS, SP1105), was read at a 
wavelength of $470 \mathrm{~nm}$ (Kubola, Meeso, \& Siriamornpun, 2013; Rodriguez-Amaya, 2001; Xue et al., 2018). The lycopene concentration in the $25 \mathrm{~mL}$ flask exceeded the upper limit, and thus, the solution was diluted by pipetting approximately $0.5 \mathrm{~mL}$ to a $5 \mathrm{~mL}$ flask. The volume was completed with petroleum ether and the readings were made. The Lycopene content was obtained by the following Equation (4).

$$
\text { Lycopene }=\mathrm{A} \times \mathrm{V} \times 10.000 \times \mathrm{D} /\left(\mathrm{m} \times E_{1 \mathrm{~cm}}^{1 \%}\right)
$$

Where, $\mathrm{A}=$ absorbance of the solution at a wavelength of $470 \mathrm{~nm}, \mathrm{~V}=$ final volume of the sample $(\mathrm{mL}) ; \mathrm{D}=$ dilution of the sample, $\mathrm{m}=$ sample weight $(\mathrm{g}), E_{1 \mathrm{~cm}}^{1 \%}=$ specific coefficient of molar absorptivity of 3450 for lycopene in petroleum ether (Rodriguez-Amaya, 2001).

The estimates of water use efficiency was based on the relationship between productivity $(\mathrm{P})$ and the volume of water applied (V), according to the following Equation (5):

$$
\mathrm{WUE}=\mathrm{P} / \mathrm{V}
$$

Where, WUE = water use efficiency $\left(\mathrm{kg} \mathrm{m}^{-3}\right), \mathrm{P}=$ productivity $(\mathrm{kg})$, and water volume $=\mathrm{V}\left(\mathrm{m}^{3}\right)$.

The results of productivity, lycopene content, and water use efficiency were analyzed by regression and the significance of the coefficient regression was submitted to the $t$ test at 0.1 to $5 \%$ probability with the statistical software R.

\section{Results and Discussion}

\subsection{The Effect of the Irrigation Depths on Yield}

As shown in Figure 1A, the highest yields of fruits in the Winter/Spring $\left(134 \mathrm{t} \mathrm{ha}^{-1}\right)$ was obtained with the irrigation depths of $534 \mathrm{~mm}$ and for the Summer/Autumn experiment $\left(106 \mathrm{t} \mathrm{ha}^{-1}\right)$, with the irrigation depth of 534 and $491 \mathrm{~mm}$. A lower yield of fruits with the application of 50\% of ETc, agreed with the results reported from similar studies with tomato and potato (Jensen et al., 2010). This also is in agreement with results reported from studies with tomato in different regions such as India (Mukherjee, Sarkar, \& Chakraborty, 2012), Italy (Marino, Aria, Basso, Leone, \& Alvino, 2014), and Saudi Arabia (Al-Harbi, Al-Omran, Alenazi, \& Wahb-Allah, 2015) 

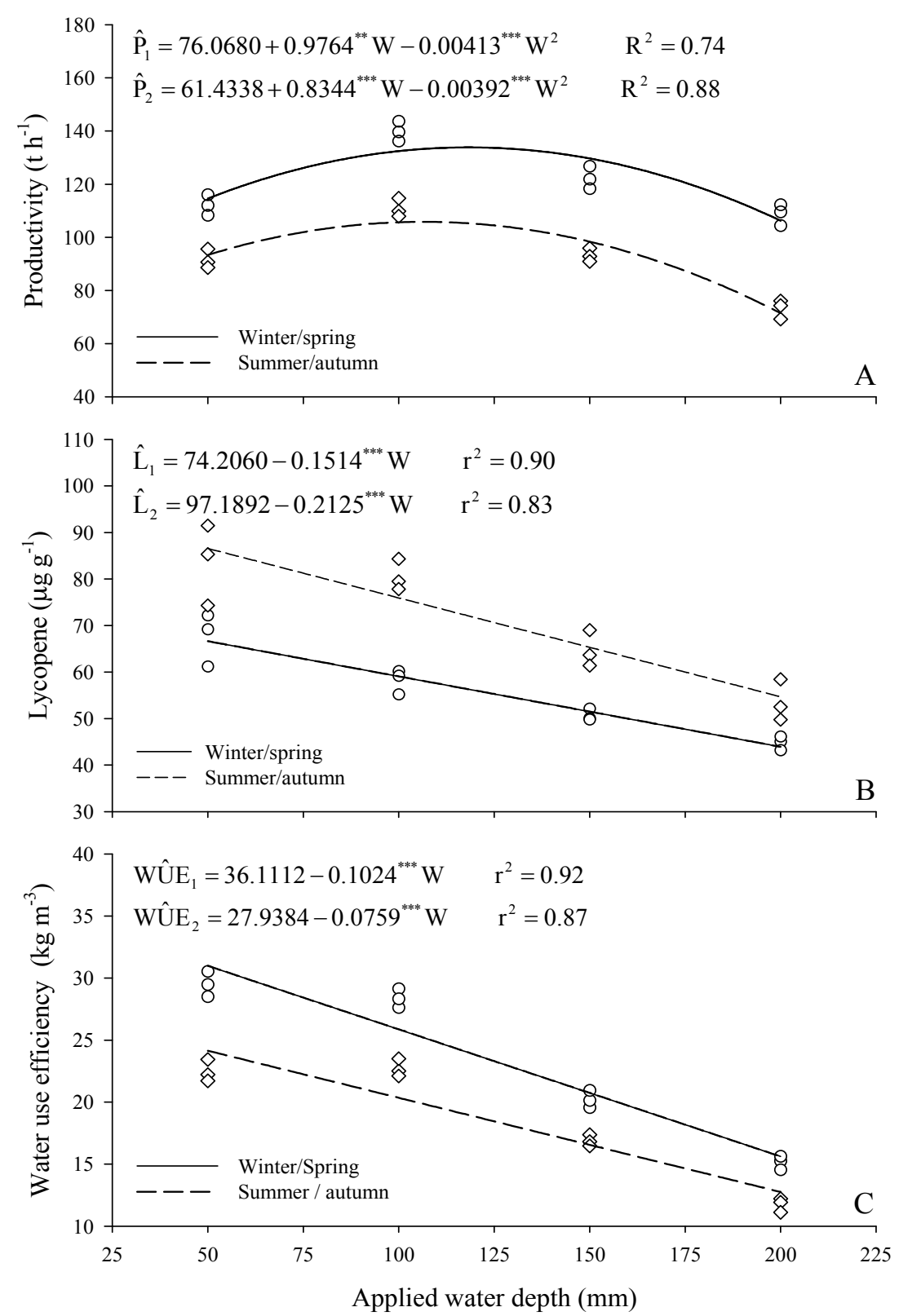

Figure 1. Productivity (A), lycopene content in fruits (B), and water use efficiency (C), in two cropping seasons and under different levels of irrigation depths. Significant at $0.1 \%{ }^{* * *}, 1 \%{ }^{* *}$ and $5 \%{ }^{*}$ by " $t$ " test

The water stress is known to reduce the growth of plants, affecting their anatomy, morphology, biochemical processes, as well as the uptaking and translocation of nutrients (Guang-Cheng, Na, Zhan-Yu, Shuang-En, \& Chang-Ren, 2010; Karimi \& Hasanpour, 2014). On the other hand, in conditions of higher availability of water, the expenditure of energy for its absorption is lower. This allows the plant to allocate more resources for photosynthesis and for the accumulation of carbohydrates, which allows the increase of productivity (Ismail \& Ozawa, 2007; Singh et al., 2011). Furthermore, some studies with crops such as tomato and alfalfa reported increase in the distribution of roots in conditions of higher availability of water (Ismail \& Ozawa, 2007; Singh et al., 2011). As a consequence, this affects the growth, development and the production of plants.

\subsection{The Effect of the Irrigation Depths on the Content of Lycopene in Fruits}

The application of the irrigation depth corresponding to $50 \%$ of ETc resulted in volumes of 380 and $409 \mathrm{~mm}$ in the Winter/Spring and Summer/Autumn experiments, respectively. This irrigation depth resulted in contents of lycopene of $66.6 \mu \mathrm{g} \mathrm{g}^{-1}$ in the first experiment, and $86.6 \mu \mathrm{g} \mathrm{g}^{-1}$ in the second (Figure 2B). 
Some studies have reported that the content of lycopene in fruits varies according to the cultivar and the season of cultivation (Dumas, Dadomo, Di Lucca, \& Grolier, 2003; Garcia \& Barrett, 2006). In terms of temperature, it has been demonstrated that the synthesis of lycopene is higher at temperatures from 16 to $21{ }^{\circ} \mathrm{C}$, and lower at temperatures above $30^{\circ} \mathrm{C}$ (Brandt, Pék, Barna, Lugasi, \& Helyes, 2006). As shown in the Figure $2 \mathrm{~A}$, the average temperature was $18.5^{\circ} \mathrm{C}$ in the first experiment, and $20.9{ }^{\circ} \mathrm{C}$ in the second, and corresponded to temperatures adequate to cultivation of tomato (Ohnishi, Miyoshi, \& Shirai, 2010; Tarchoun, M'Hamdi, \& Silva, 2012). The total precipitation corresponded to $257.4 \mathrm{~mm}$ in the first experiment, and to $315.4 \mathrm{~mm}$ in the second (Figure 2A).
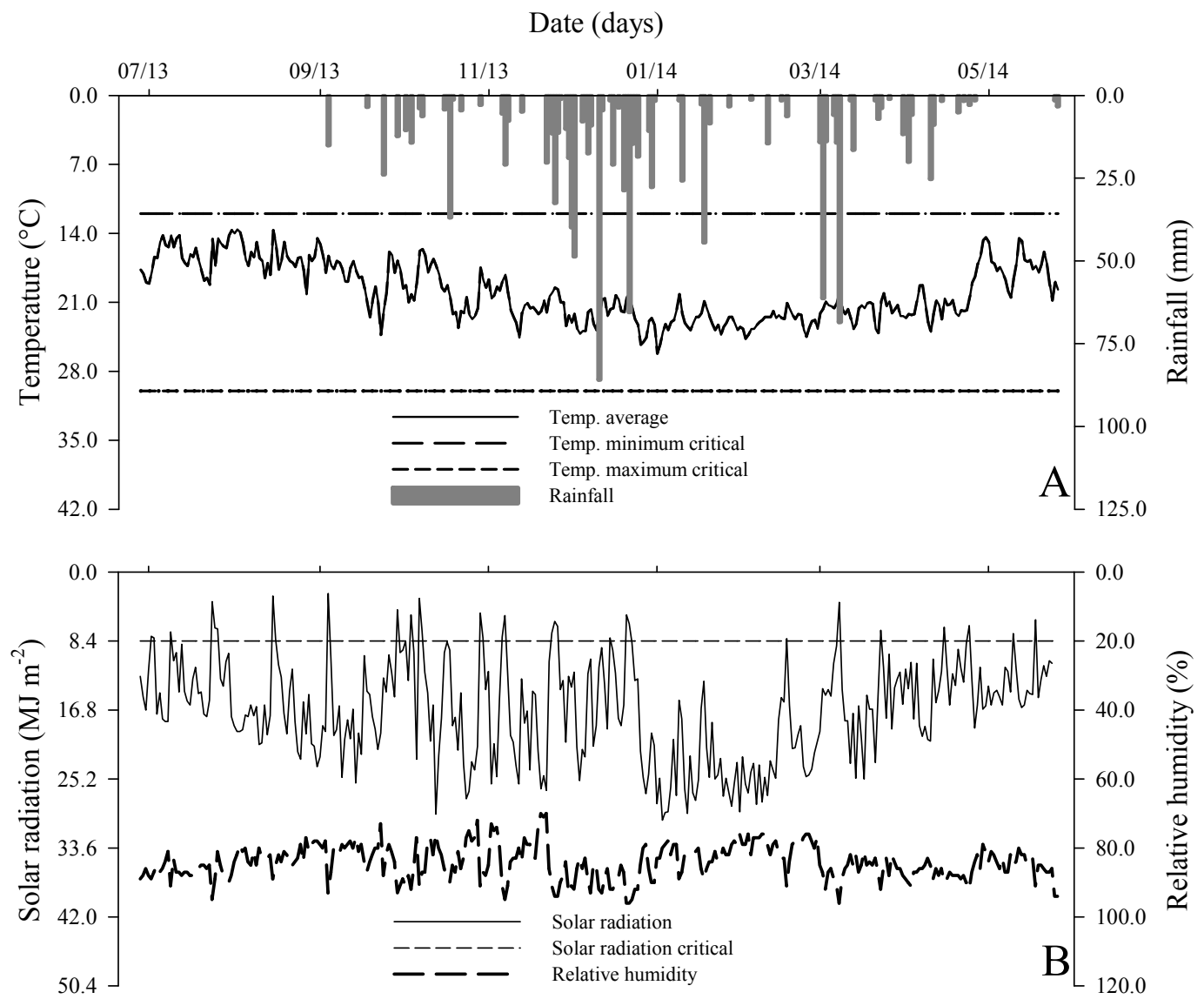

Figure 2. Average, minimum and maximum critical temperatures, precipitation (A); solar radiation, specific solar radiation, and relative humidity (B), during the experiments in Viçosa, Minas Gerais, Brazil

Pernice et al. (2010), reported a maximum production of tomato with the reduction of the irrigation depth, in Salerno, Italy. Corroborating this, other studies have associated the increase in the synthesis of lycopene and other carotenoids to conditions of water stress (Dorais, Ehret, \& Papadopoulos, 2008). According to Dorais et al. (2008), the limitation in the supplying of water favors the synthesis of the abscisic acid on roots, which distribute this component to the entire plant, increasing the synthesis of ethylene and carotenoids.

\subsection{The Effect of the Irrigation Depths on the Water Use Efficiency}

The maximum efficiency in the water use was recorded with the application of $380 \mathrm{~mm}$ and $409 \mathrm{~mm}\left(50 \% \mathrm{ET}_{\mathrm{C}}\right)$. This first volume corresponded to a WUE of $31.0 \mathrm{~kg} \mathrm{~m}^{-3}$ and the second to $31.0 \mathrm{~kg} \mathrm{~m}^{-3}$ (Figure 2C). The higher WUE of plants at $50 \%$ ETc agreed with the results obtained with the application of lower irrigation depths in this crop in Turkey (Topcu et al., 2007), Southern Italy (Patanè et al., 2011) and Saudi Arabia (Al-harbi et al., 2015).

The estimates of WUE with the application of $50 \%$ of the irrigation depth in this study ( 31.0 and $24.1 \mathrm{~kg} \mathrm{~m}^{-3}$ ) where higher than the values reported by Ismail and Mousa (2014), which observed WUE values of $19.2 \mathrm{~kg} \mathrm{~m}^{-3}$. However, the results found in the present study are similar to the ones obtained by Marino et al. (2014) and Al-harbi et al. (2015), which reported WUE values of 35.1 and $31.4 \mathrm{~kg} \mathrm{~m}^{-3}$, respectively. According to some 
studies, the greater use of water in conditions of water deficit stems from the reduction of losses by evaporation (Geerts \& Raes, 2009; Steduto \& Albrizio, 2005). Additionally, water deficit can stimulate the development and distribution of roots, which promotes a higher absorption of water and nutrients, resulting in higher productivity.

As shown in Figure 3, the best combination of the three components (productivity, content of lycopene and WUE) was recorded with the application of $100 \%$ ETc (Figure 3). The market does not pay for the content of lycopene in the fruits of tomato, thus, the irrigation depth of $100 \% \mathrm{ETc}$, capable of providing higher productivity, should be used as reference in the production of tomato. The content of lycopene of fruits with this irrigation depth corresponded to 59.1 in the Winter/Spring and to $75.9 \mu \mathrm{g} \mathrm{g}^{-1}$ in the Summer/Autumn, experiments.
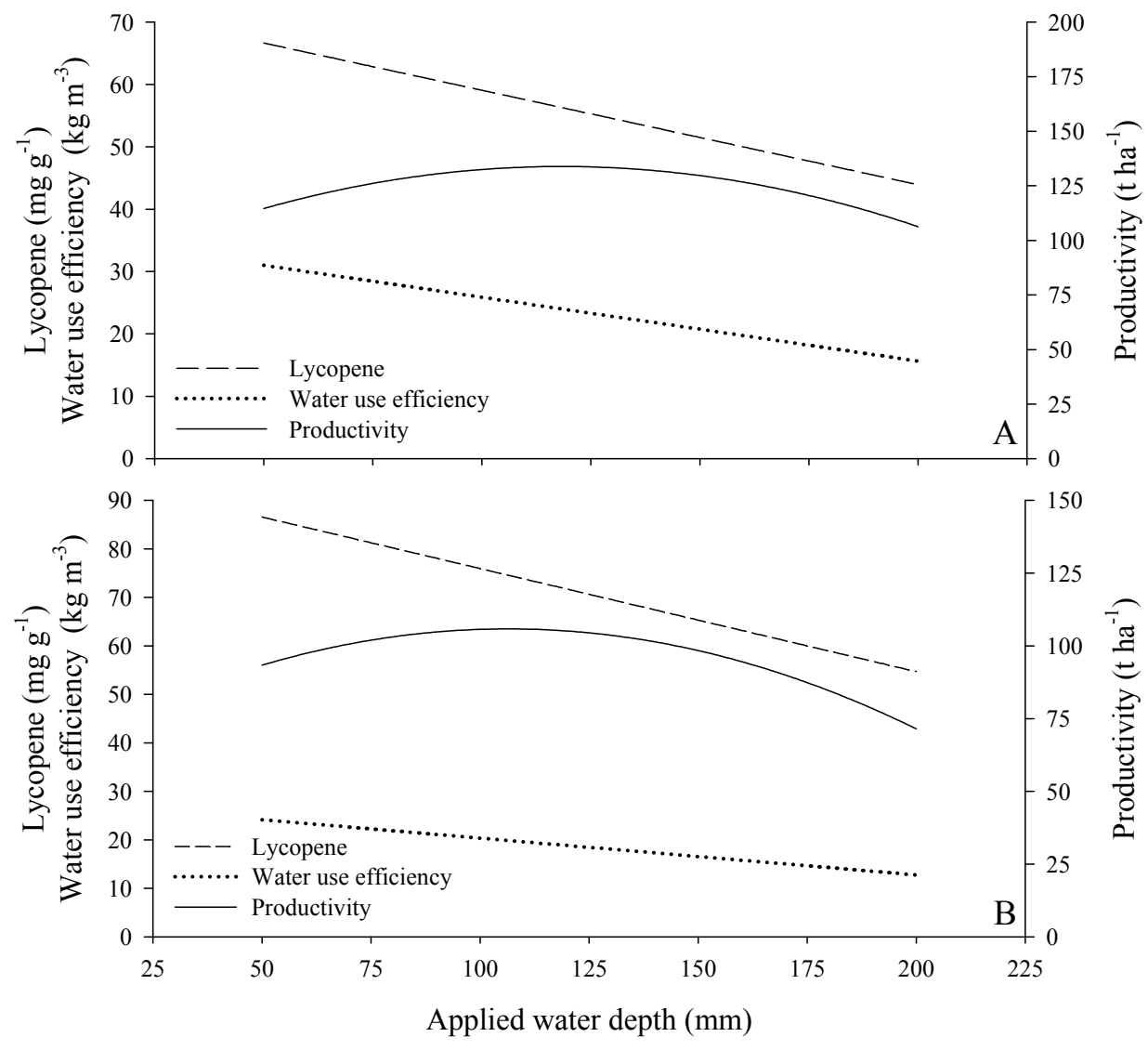

Figure 3. Productivity, content of lycopene in fruits, and water use efficiency in the two cropping seasons Winter/Spring (A), and Summer/Autumn (B), under different irrigation depths

\section{Conclusion}

The levels of irrigation affected the productivity, the content of lycopene in fruits and the water use efficiency. The yield of fruits was higher with the application of $112 \%$ of the irrigation depth recommended for this crop. The content of lycopene and the water use efficiency were maximum with the application of $50 \%$ of the irrigation depth recommended for this crop. The irrigation depth of $100 \%$ provided the best combination of the components under study (higher productivity, higher lycopene content, and higher water use efficiency).

\section{References}

Aidoud, A., Ammouche, A., Garrido, M., \& Rodriguez, A. B. (2014). Effect of lycopene-enriched olive and argan oils upon lipid serum parameters in Wistar rats. Journal of the Science of Food and Agriculture, 94(14), 2943-2950. https://doi.org/10.1002/jsfa.6638

Al-Harbi, A. R., Al-Omran, A. M., Alenazi, M. M., \& Wahb-Allah, M. A. (2015). Salinity and deficit irrigation influence tomato growth, yield and water use efficiency at different developmental stages. International Journal of Agriculture \& Biology, 2, 241-250.

Allen, R. G., Pereira, L. S., Raes, D., \& Smith, M. (1998). Crop evapotranspiration—Guidelines for computing 
crop water requirements. Irrigation and Drainage Paper 56. United Nations FAO, Rome.

Brandt, S., Pék, Z., Barna, É., Lugasi, A., \& Helyes, L. (2006). Lycopene content and colour of ripening tomatoes as affected by environmental conditions. Journal of the Science of Food and Agriculture, 86(4), 568-572. https://doi.org/10.1002/jsfa.2390

Caliman, F. R. B., Silva, D. J. H., Stringheta, P. C., Fontes, P. C. R., Moreira, G. R., \& Mantovani, E. C. (2010). Quality of tomatoes grown under a protected environment and field conditions. Idesia, 28(2), 75-82.

Dorais, M., Ehret, D. L., \& Papadopoulos, A. P. (2008). Tomato (Solanum lycopersicum) health components: From the seed to the consumer. Phytochemistry Reviews, 7(2), 231-250. https://doi.org/10.1007/s11101-007 $-9085-\mathrm{X}$

Dumas, Y., Dadomo, M., Di Lucca, G., \& Grolier, P. (2003). Effects of environmental factors and agricultural techniques on antioxidantcontent of tomatoes. Journal of the Science of Food and Agriculture, 83(5), 369-382. https://doi.org/10.1002/jsfa. 1370

Garcia, E., \& Barrett, D. M. (2006). Assessing lycopene content in california processing tomatoes. Journal of Food Processing and Preservation, 30(1), 56-70. https://doi.org/10.1111/j.1745-4549.2005.00047.x

Geerts, S., \& Raes, D. (2009). Deficit irrigation as an on-farm strategy to maximize crop water productivity in dry areas. Agricultural Water Management, 96(9), 1275-1284. https://doi.org/10.1016/j.agwat.2009.04.009

Guang-Cheng, S., Na, L., Zhan-Yu, Z., Shuang-En, Y., \& Chang-Ren, C. (2010). Growth, yield and water use efficiency response of greenhouse-grown hot pepper under Time-Space deficit irrigation. Scientia Horticulturae, 126(2), 172-179. https://doi.org/10.1016/j.scienta.2010.07.003

Hanson, B. R., \& May, D. M. (2006). Crop evapotranspiration of processing tomato in the San Joaquin Valley of California, USA. Irrigation Science, 24(4), 211-221. https://doi.org/10.1007/s00271-005-0020-X

Ismail, S. M., \& Almarshadi, M. H. (2013). Maximizing productivity and water use efficiency of alfalfa under precise subsurface drip irrigation in arid regions. Irrigation and Drainage, 62(1), 57-66. https://doi.org/ 10.1002/ird.1705

Ismail, S. M., \& Mousa, M. A. A. (2014). Optimizing tomato productivity and water use efficiency using water regimes, plant density and row spacing under arid land conditions. Irrigation and Drainage, 63(5), 640-650. https://doi.org/10.1002/ird.1868

Ismail, S. M., \& Ozawa, K. (2007). Improvement of crop yield, soil moisture distribution and water use efficiency in sandy soils by clay application. Applied Clay Science, 37(1-2), 81-89. https://doi.org/10.1016 /j.clay.2006.12.005

Jensen, C. R., Battilani, A., Plauborg, F., Psarras, G., Chartzoulakis, K., Janowiak, F., ... Andersen, M. N. (2010). Deficit irrigation based on drought tolerance and root signalling in potatoes and tomatoes. Agricultural Water Management, 98(3), 403-413. https://doi.org/10.1016/j.agwat.2010.10.018

Karatas, B. S., Akkuzu, E., Unal, H. B., Asik, S., \& Avci, M. (2009). Using satellite remote sensing to assess irrigation performance in Water User Associations in the Lower Gediz Basin, Turkey. Agricultural Water Management, 96(6), 982-990. https://doi.org/10.1016/j.agwat.2009.01.010

Karimi, H. R., \& Hasanpour, Z. (2014). Effects of salinity and water stress on growth and macro nutrients concentration of pomegranate (Punica granatum L.). Journal of Plant Nutrition, 37(12), 1937-1951. https://doi.org/10.1080/01904167.2014.920363

Kong, K.-W., Khoo, H.-E., Prasad, K. N., Ismail, A., Tan, C.-P., \& Rajab, N. F. (2010). Revealing the power of the natural red pigment lycopene. Molecules (Basel, Switzerland), 15(2), 959-987. https://doi.org/ 10.3390/molecules15020959

Korir, N. K., Diao, W., Tao, R., Li, X., Kayesh, E., Li, A., ... Wang, S. (2014). Genetic diversity and relationships among different tomato varieties revealed by EST-SSR markers. Genetics and Molecular Research, 13(1), 43-53. https://doi.org/10.4238/2014.January.8.3

Kubola, J., Meeso, N., \& Siriamornpun, S. (2013). Lycopene and beta carotene concentration in aril oil of gac (Momordica cochinchinensis Spreng) as influenced by aril-drying process and solvents extraction. Food Research International, 50(2), 664-669. https://doi.org/10.1016/j.foodres.2011.07.004

Li, X., Shi, H., Šimůnek, J., Gong, X., \& Peng, Z. (2015). Modeling soil water dynamics in a drip-irrigated intercropping field under plastic mulch. Irrigation Science, 33(4), 289-302. https://doi.org/10.1007/ 
s00271-015-0466-4

López-Mata, E., Tarjuelo, J. M., de Juan, J. A., Ballesteros, R., \& Domínguez, A. (2010). Effect of irrigation uniformity on the profitability of crops. Agricultural Water Management, 98(1), 190-198. https://doi.org/ 10.1016/j.agwat.2010.08.006

Madani, A., Makarem, A., Vazin, F., \& Joudi, M. (2012). The impact of post-anthesis nitrogen and water availability on yield formation of winter wheat. Plant, Soil and Environment, 58(1), 9-14. https://doi.org/ 10.17221/299/2011-PSE

Marino, S., Aria, M., Basso, B., Leone, A. P., \& Alvino, A. (2014). Use of soil and vegetation spectroradiometry to investigate crop water use efficiency of a drip irrigated tomato. European Journal of Agronomy, 59, 67-77. https://doi.org/10.1016/j.eja.2014.05.012

Mukherjee, A., Sarkar, S., \& Chakraborty, P. K. (2012). Marginal analysis of water productivity function of tomato crop grown under different irrigation regimes and mulch managements. Agricultural Water Management, 104, 121-127. https://doi.org/10.1016/j.agwat.2011.12.006

Navarro, J. M., Botía, P., \& Pérez-Pérez, J. G. (2015). Influence of deficit irrigation timing on the fruit quality of grapefruit (Citrus paradisi Mac.). Food Chemistry, 175, 329-336. https://doi.org/10.1016/j.foodchem. 2014.11.152

Navarro, J. M., Pérez-Pérez, J. G., Romero, P., \& Botía, P. (2010). Analysis of the changes in quality in mandarin fruit, produced by deficit irrigation treatments. Food Chemistry, 119(4), 1591-1596. https://doi.org/10.1016/ j.foodchem.2009.09.048

Ohnishi, S., Miyoshi, T., \& Shirai, S. (2010). Low temperature stress at different flower developmental stages affects pollen development, pollination, and pod set in soybean. Environmental and Experimental Botany, 69(1), 56-62. https://doi.org/10.1016/j.envexpbot.2010.02.007

Ozbahce, A., Tari, A. F. (2010). Effects of different emitter space and water stress on yield and quality of processing tomato under semi-arid climate conditions. Agricultural Water Management, 97, 1405-1410. https://doi.org/10.1016/j.agwat.2010.04.008

Patanè, C., Tringali, S., \& Sortino, O. (2011). Effects of deficit irrigation on biomass, yield, water productivity and fruit quality of processing tomato under semi-arid Mediterranean climate conditions. Scientia Horticulturae, 129(4), 590-596. https://doi.org/10.1016/j.scienta.2011.04.030

Pernice, R., Parisi, M., Giordano, I., Pentangelo, A., Graziani, G., Gallo, M., ... Ritieni, A. (2010). Antioxidants profile of small tomato fruits: Effect of irrigation and industrial process. Scientia Horticulturae, 126(2), 156-163. https://doi.org/10.1016/j.scienta.2010.06.021

Perveen, R., Suleria, H. A. R., Anjum, F. M., Butt, M. S., Pasha, I., \& Ahmad, S. (2015). Tomato (Solanum lycopersicum) carotenoids and lycopenes chemistry; metabolism, absorption, nutrition, and allied health claims-A comprehensive review. Critical Reviews in Food Science and Nutrition, 55(7), 919-929. https://doi.org/10.1080/10408398.2012.657809

Rodriguez-Amaya, D. B. (2001). A guide to carotenoid analysis in foods.

Singh, B., Chandra, A., \& Singh, R. (2011). Determination of root distribution in ber (Ziziphus mauritiana) by root excavation. Indian Journal of Agricultural Sciences, 81(5), 473-475.

Steduto, P., \& Albrizio, R. (2005). Resource use efficiency of field-grown sunflower, sorghum, wheat and chickpea. Agricultural and Forest Meteorology, 130(3), 269-281. https://doi.org/10.1016/j.agrformet. 2005.04.003

Tapiero, H., Townsend, D. M., \& Tew, K. D. (2004). The role of carotenoids in the prevention of human pathologies. Biomedicine \& Pharmacotherapy, 58(2), 100-110. https://doi.org/10.1016/j.biopha.2003. 12.006

Tarchoun, N., M'Hamdi, M., \& Silva, J. A. T. (2012). Approaches to evaluate the abortion of hot pepper floral structures induced by low night temperature. European Journal of Horticultural Science, 77(2), 78-83.

Topcu, S., Kirda, C., Dasgan, Y., Kaman, H., Cetin, M., Yazici, A., \& Bacon, M. A. (2007). Yield response and $\mathrm{N}$-fertiliser recovery of tomato grown under deficit irrigation. European Journal of Agronomy, 26(1), 64-70. https://doi.org/10.1016/j.eja.2006.08.004

Valenciano, J. D. P., \& Toril, J. U. (2015). Control System of Management for Intensive Cultivation Activity in 
Tomato Production: Spanish Case. Journal of Agricultural Science and Technology, 17(1), 11-21.

Xue, L., Wei, F., Gao, G., Yan, G., Song, W., Chen, B., \& Wu, X. (2018). Development of an ultrasound-assisted extraction method for the rapid quantification of seed carotenoid content in oilseed rape. Crop and Pasture Science, 69(1), 48. https://doi.org/10.1071/CP16351

\section{Copyrights}

Copyright for this article is retained by the author(s), with first publication rights granted to the journal.

This is an open-access article distributed under the terms and conditions of the Creative Commons Attribution license (http://creativecommons.org/licenses/by/4.0/). 